\title{
OPS AND THE PROBLEM OF SMALL BUSINESS $\dagger$
}

\author{
JESSE ROBISON* \\ INTRODUCTION
}

The imposition of price controls inevitably lays burdens on all business, large as well as small. That is a part of the cost of combating inflation. But small business argues that it has special problems not faced by big business; its difficulties are intensified under price controls; it is less able to bear up under these burdens; and, unless special precautions are taken, the injury done to the basic small business economy may more than offset the advantages deriving from the control program.

There is a further argument, supported by ample evidence, that if price control techniques are not keyed to typical small business practices, general compliance from small business cannot be expected. Then the program loses public support; respect for law is diminished; and a generally unpleasant and politically unhealthy condition prevails.

This sequence can be avoided by assuming from the beginning that a price control program must be planned with small business consciously in mind. In fact, those parts of the program primarily involving small business could well be labelled "for small business."

What are the principal differences between small and big business that call for special treatment in a price control program? They are: ( $\mathrm{x}$ ) inadequacy of business records with respect to the requirements of tight control techniques, (2) inadequacy of personnel, and (3) inadequacy of finances. Without the financial resources of big business, the small businessman generally cannot pay for the additional recordkeeping and the reporting that is required under controls; nor can he hire the additional personnel necessary to keep the records and make the necessary reports. Moreover, in a great many cases he cannot withstand the financial shock of even a temporary squeeze on profits which might occur in a period of inflation.

It is the natural tendency of any control agency to adopt the policy of a single set of regulations for all businesses. That is the relatively easy way. Development of major and minor control regulations for every industry would raise many complex administrative issues. Regulations tend to be directed toward the bulk, if not all, of the sales volume of any controlled commodity or service. Special situations, it is assumed, will be handled on an individual basis. However, if all small business becomes a special situation, the great mass of sellers must be treated individually, at

\footnotetext{
t The opinions expressed herein are the author's and do not necessarily reflect those of any past or present Government agency.

- A.B. I922, Harvard University; formerly Special Assistant to the Director for Price Operations and Chairman, Adjustment Coordinating Committee, Office of Price Stabilization; various executive posts in government including Secretary of Smaller War Plants Corporation; currently with Robert R. Nathan Associates, Inc., Washington, D. C. Publications include, Editor, Washington Small Business Newsletter, 1946-1947, and articles in popular magazines on financial subjects.
} 
an administrative cost for government and business all out of proportion to the volume of sales involved.

Faced with the difficulties of beginning operations with virtually no organization, and assuming a continuation of the strong inflationary trend of prices, OPS originally took the approach that its regulations should apply uniformly to all businesses regardless of size. ${ }^{1}$

\section{I}

\section{Statutory Background and National Policy}

From its very birth, OPS was under strict instructions from the Congress to give full consideration to the problems of small business. This was implicit in Title IV, Section 401 of the Defense Production Act of $195^{0}:^{2}$

It is the intent of Congress that the Authority conferred by this title shall be exercised. ... in particular with full consideration and emphasis, so far as practicable, on the maintenance and furtherance of the American system of competitive enterprise, including independent small-business enterprises. ...

The intent of Congress was clear. Moreover, this statement was merely a reaffirmation of a long standing policy by the Congress towards small business. One has only to recall that during World War II Congress established the Smaller War Plants Corporation, which was a special agency devoted to aiding small businesses and to promoting their special consideration in the programs of the war agencies.

The Defense Production Act of $195^{\circ}$ made no effort to define small business except as implied in the qualifying adjective "independent." However, the I95I Amendments did give an indication in Section 714,3 which stated that "For the purposes of this section [the establishment of the Small Defense Plants Administration], a small-business concern shall be deemed to be one which is independently owned and operated and which is not dominant in its field of operation." For its own purposes, the SDPA could expand this criterion on the basis of number of employees, dollar volume of business, independency of ownership, and non-dominance in its field. While this definition was not binding on, nor particularly instructive to OPS whose interest and responsibility extended not only to "plants," but to virtually the whole business economy, including wholesalers, retailers, and service establishments, it was officially adopted by the agency as a guide to its field organizations.

In the course of its development, OPS generally used a physical or dollar volume cut-off in granting relief to particular groups of smaller businesses. In manufacturing, cut-off levels varied from $\$ 1,000,000$ to $\$ 25,000$ sales volume per year.

\footnotetext{
${ }^{1}$ Some exceptions could be cited. For example, home manufacturing operations unassisted, which did not exceed \$200 a month, were exempted under GCPR. I6 FED. REG. 808 (I95I). Similarly, sales of "stamps and coins, precious stones, paintings, other objects of art, and commodities made prior to 1850" were exempted. These exemptions did not reflect a significant policy oricntation to small business.

${ }^{2} 64$ STAT. 803 (1950), 50 U. S. C. App. \$2ror (Supp. 1952).

${ }^{3} 65$ STAт. I39 (I95I), 50 U. S. C. App. \$2163(a) (I) (Supp. 1952).
} 
Under the construction services regulation, CPR $93,{ }^{4}$ one-man shops were exempted. DR I ${ }^{5}$ relieved slaughterers killing less than 100,000 lbs. live weight per year of reporting requirements. A similar concession was made to bituminous coal mines producing under roo tons per day. In other words, OPS was not wedded to any single definition or any single basis of defining small business.

\section{II}

\section{EARLY PROBLEMS}

Even in its formative stages, OPS was at least aware that smaller business might have problems which demanded special treatment. Before the agency was really organized, in December I950, a task committee was organized to develop a retailers' regulation, and included representatives from the National Retail Furniture Association, the American Retail Federation, and the National Association of Men's Clothiers and Furnishers. They were presumed to reflect the viewpoints of their small store members. The consultant who directed the drafting of the retailers' regulation was the former owner and operator of two small apparel stores. The result of this effort, CPR 7, which was issued just one month after the general freeze, was believed, therefore, to be well adapted to small storekeepers. ${ }^{6}$ Later reports from industry and OPS field offices indicated that this assumption was not valid.

The earliest problems faced by OPS were those created by the GCPR, issued January 26 , 195I. Being a general freeze order, it inevitably caught and held distortions in normal cost-price relationships. Profit margins were squeezed in many cases.

Relief from squeezed margins was the first and most urgent problem of small business after price controls were imposed. This relief presumably was extended through individual adjustment provisons and "tailored" regulations. The former would allow the merchant or manufacturer to petition for and justify an increased price for a commodity or service. The latter would lay down a basis or formula for calculating a new ceiling price which would reestablish normal profits or profit margins.

This double program for restoring normal relationships in prices created new problems. The first was that the data and computations required to justify individual adjustments and to calculate new prices or margins frequently were beyond the capacity or accounting resources of the smaller businessman.

Second, as tailored regulations were issued for commodity after commodity, a great many businesses found themselves subject to an increasing number of regulations, each with special reporting and record-keeping requirements, pricing techniques, adjustment provisions, etc.

4 6 FED. REG. II592 (I95I).

EId. at 4456 (195I).

'Id. at 1872 (195I). The Task Committee issued a statement of policy on Dec. 8, I950 which stated that retailers "found that regulations of the type of (OPA) MPR 580 freezing markups by merchandise categories and price lines on the basis of the individual seller's own experience" proved satisfactory. 
The various technical measures taken by OPS to help smaller businesses in the framework of price control can be grouped as follows: adjustments, premium pricing, pricing methods, relaxed reporting and record-keeping, and exemptions.

\section{III}

\section{Small Business Representation in OPS}

One of the first official acts of OPS to reflect its growing awareness of a small business problem was the Director's designation in March 1951 of a special assistant to accompany the House Small Business Committee on a cross-country series of hearings.

While the hearings were in progress, the OPS representative recommended that ${ }^{7}$

A small business representative who actually is a small businessman should be appointed to your staff and then be allowed to sit in on any industry committee meeting where regulations are being drawn, etc., to see that Small Business is represented and its problems covered. Small Business Committees should be organized in each office.

A few months later, on August I, I95I, the Director of OPS issued a general policy on small business. While there was little new in the statement, it could and probably did serve to some degree as a check for the regulation drafters. More important and more promising were the announcements of (a) small business representatives in the field offices, and (b) the Assistant to the Director for Small Business.

This particular organizational arrangement which avoided an Office of Small Business with operating responsibilities, reflected the strong feeling in the Director's staff (the majority view) that the agency should avoid giving the impression that small business constituted a special and separate program. They took the position that price control affected all sellers, and the OPS approach was to be national and comprehensive rather than divided by segments of the economy.

The incumbent of the position of Assistant for Small Business continued to the end of his tenure unsuccessfully to press for greater authority, more staff, and more active participation in both policy and program developments.

\section{IV}

\section{Small Business on Industry Advisory Committrees}

It was believed, or hoped, that small business representatives on industry advisory committees would ensure the feasibility of regulations for small operators. At least, it would defend OPS from the charge of ignoring small business.

However, not all of the OPS industry advisory committees can be said to have had true small business representation. In general, the small businessman who is sufficiently interested, who can take the time and will spend the money to join a committee and attend its meetings, is closer to thinking and acting as a big businessman than the general run of small operators. Consequently, he is likely to agree to the reasonableness of a technical pricing method, or to some other proposed

\footnotetext{
${ }^{7}$ Memorandum, McCormick to DiSalle, April II, I95I.
} 
requirement of a price control regulation, which is not feasible for other companies in his class and smaller.

Unfortunately, most small businessmen can speak only in terms of their own simple operating procedures. Since ways of doing business in any trade are virtually infinite in variety, it is difficult if not impossible to get true cross-section representation of small business without creating a completely unwieldy committee.

Certainly the experience of OPS indicates that stronger efforts should be made to get the views of small businessmen into the formulation of price control regulations at minimum cost of travel and time.

\section{$\mathrm{V}$}

\section{Field Operations}

For effective administration vis a vis small business, a price control program must be at the district office level. There may be some exceptions in manufacturing. On the whole, however, information, education, interpretation, processing of adjustments, price determinations, filings, registration, and all the other appurtenances of price control must be handled as near as possible to the place of (small) businessor small business suffers and the program breaks down.

This costs money, more money than any taxpayer likes to see spent for a product with the bitter taste of preventive medicine. But the alternative to high cost, for these purposes, is token control.

The apparent difficulty-as it developed in OPS-lay in the speed with which the field organizations were organized and trained to process price actions and in the extent to which authority was delegated to the field administrators.

Since price actions (authorizations, adjustments, etc.) were a fraction of the total job, the emphasis on delegations in this area may obscure the fact that the other functions of the field offices were undervalued by the field personnel.

Operating personnel in the national office believed that field offices could not process with the same degree of precision and astuteness as national office personnel who were considered much more expert and trained in the policies and techniques of price control. It was claimed, furthermore, that there were specialists in all trade areas in the national office while the field operating officials could not be specialists in all the areas in which they had responsibility.

It was also contended in the national office that it was not possible to write operating instructions for field offices which conveyed the meaning or policies of the regulation in sufficiently clear and precise language to insure even-handed justice throughout the country in all the offices. It is a question, however, whether that continued to be true for very long after field offices were adequately staffed and had been given an adequate training program.

It is certainly true of the situation in OPS that, particularly in the early days, there were not enough people in the commodity divisions to write regulations, process applications, prepare operating instructions, and carry out all the other duties which engulfed the agency. 
Moreover, there is a very grave question as to whether the whole problem of delegations to the field was magnified out of proportion to its true significance. Adjustments, for example, were expected to impose a heavy workload on the field staffs, to the extent of hundreds of thousands of applications for increases in ceiling prices. As a matter of fact, in Washington and the field, only 38,000 applications were received in the two and one-half years of the agency's existence. This may have been due to the fact that prices turned soft, and for many commodities higher ceiling prices could not have been put into effect if they had been granted.

It must be admitted that there was considerable noncompliance among small firms. Merchants and storekeepers adjusted their prices without obtaining the required approval. In some of the service industries, for example, the index of prices rose steadily without any indication in adjustment applications that there was a pressure for higher prices. The explanation of such a phenomenon is, of course, noncompliance. ${ }^{8}$

It might be pointed out also that, although delegations went reluctantly from the national office to the regional offices, the latter were similarly reluctant to redelegate to district offices. To serve an extensive small business community adequately, a field organization must be at the grass roots or district office level.

The relative efficiency of field offices versus the national office in processing applications was exposed in a study made in July, I952, of the time it took in the district, regional and national offices to process adjustments. This study showed that the median time for processing applications was 47 days in the district offices, 37 days in the regional offices, and 55 days in the national office. It would appear that the national office claim for the greater efficiency of its specialists is not supported by the record. However, the greater complexity of the typical application received by the national office and its many other operating responsibilities may account in part for its apparent lower efficiency.

A study of field operations and the problem of delegating authority to field offices is the subject of another paper in this series. Suffice to say at this point that the policy officials in the national office made constant efforts to accelerate the program of delegating to the field. The field offices were constantly clamoring for such delegations, in part to meet the complaints of delays in processing by the Washington office and in part because of the need for a workload which would justify the staffs which they had recruited. The commodity divisions were not eager to delegate, but gradually and increasingly did delegate, with a few exceptions.

\section{VI}

\section{Some Problem Areas}

The principal small business problem areas for OPS would naturally be among those industries or trades in which small business establishments are most numerous. Therefore, most of the difficulties felt by OPS arose from the retail and service areas.

\footnotetext{
${ }^{8}$ See index of shoe repair prices, 1950-1952. There were no applications for adjustment of charges for shoe repair services.
} 
Of course, it should be noted that complaints and "problems" are not to be expected when the regulation is overly liberal, where market prices have receded from fixed ceilings, where dollars-and-cents ceilings were established, or where there is widespread noncompliance.

There were many small business problem areas. For purposes of illustration four broad areas are discussed briefly, too briefly to give more than an indication of the difficulties which arose for small business and OPS under the regulations devised.

\section{A. General Merchandise Stores}

Probably no OPS regulation was the target of so many attacks as CPR 7 (supra note 6)-the regulation covering general merchandise retailers. This regulation was patterned after MPR 580 of OPA, and was formulated with the cooperation of a group of retail representatives, including some presumably speaking for small businessmen and looking out for their interests. It is probable, however, that these small business representatives were more characteristic of the minority of technically minded smaller retailers than the great mass of rule-of-thumb operators.

CPR 7 required the small merchant to make a chart showing normal spreads between costs and selling prices of all the categories of items sold by him. This was the principal objection to the regulation. Preparation of the chart required invoices as of the base period, knowledge of the selling prices of every item sold in the base period, and computations which the small retailer was unable or unwilling to make. The monumental mass of the regulation, about 35,000 words originally and 70,000 words ultimately, was an insuperable obstacle to many small merchants. Their cry was brief: "We can't live with this regulation."

To make matters worse, if possible, a great many small retailers found themselves still subject to GCPR on many items they sold and to perhaps half a dozen tailored regulations. This was the case if they sold such items as tobacco, candy, soft drinks, gasoline, and tires. OPS was continually exhorted from all sides to simplify the application of price controls to small retailers.

The long and fruitless efforts of the Consumer Goods Division to devise a reasonable and effective small retailers' regulation will not be described here. If the experience of OPS teaches any lesson, it is that a regulation like CPR 7 (and OPA's MPR 580) cannot be applied to small retailers. While a feasible substitute has not yet been found, if plans are made for a possible reimposition of price controls in another emergency, it would be well to accept the premise that a CPR 7 technique will not work for small retailers and to develop, in advance, a control mechanism that is practicable for small stores.

In this connection, it should be noted that the Small Retailers' Subcommittee of the Retailers' Advisory Committee finally agreed that any store which did less than $\$ 10,000$ total volume in a year would be treated as a small retailer. With this cut-off point, about 80 per cent of the total number of retailers under the jurisdiction of the Distribution Branch of the Consumer Goods Division would have been tagged "small." However, they accounted for only 20 per cent of total sales volume in this 
field. Under those conditions, some degree of laxity can be afforded since (a) the great bulk of retail volume would remain under tight control, and (b) it can be assumed that many of the prices charged by small stores will be governed competitively by the ceilings of the large stores, including chains and mail order concerns. The latter is not necessarily true in sparsely settled areas or in periods of strong inflationary pressures.

The small retailing field presents a fluid and rapidly changing situation with an infinite number of merchandising practices, accounting systems, additions of new sellers, and differences of size and character of selling establishments, etc. That a simple small retailers' regulation can possibly be devised to deal effectively with this situation is seriously doubted by many who worked in both OPA and OPS. There are many, also, who believe it can be done.

\section{B. Restaurants}

Restaurants and lunch counters constitute one of the most widely dispersed and typical small business operations. It is estimated that there are over 500,000 establishments in the United Sates serving foods and beverages for consumption on the premises. About 60 per cent do less than $\$ 30,000$ in annual volume, but they account for less than 25 per cent of total sales.

Yet, the first restaurant regulation-CPR Ir, effective April $\mathrm{x}$, $195 \mathrm{I}^{\circ}-$ proved entirely inappropriate to small operators, as was quickly evidenced by complaints to the OPS field offices.

For example, ${ }^{\text {a }}$

CPR II: The loudest "squawk" we receive on this regulation is that it covers every variety of food vending establishment from a hot dog stand to a sumptuous hotel. There are many small enterprises that come under the definition of restaurant that can't possibly keep the figures necessary to comply with the requirements thereof. There should be some minimum exemption by dollar volume. We recommnd figure of $\$ 10,000$. Although in New England establishments grossing less than \$10,000 a year constitute approximately $15 \%$ of the total number of restaurants, their sales amount to only $2 \%$ or $3 \%$ of the total sales.

CPR II was constructed on the basis of data which could be furnished by large restaurants, but which small restaurants could not provide except at an exorbitant expense. The technique of control was based upon the "food cost per dollar of sales." It was assumed that the term was commonly used and understood by the trade. In fact, however, only large operators maintained the sort of records which accurately showed their food cost ratio. Only such large operators make a practice of taking frequent inventories. CPR II required that inventories be taken at least three times a year. To comply with the regulation, many small firms would have been or were forced to employ accountants or bookkeepers. Their small profit margin could not absorb this extra cost. A substitute dollars-and-cents regulation

${ }^{\circ}$ I6 FED. REG. 2391 (195I).

${ }^{\text {} 2}$ Excerpt from Region I, Small Busines Report, to Leo H. McCormick, Oct. 23, 195I. 
was issued on March 28, I952, as CPR $134{ }^{10}$ which froze restaurant charges as of a new base period, the week of February 3 to 9, I952. Since food prices had begun to stabilize and the accounting requirements of CPR II were abandoned, the complaints from small restaurants subsided.

Toward the close of OPS activities, the possibility of exempting small business began seriously to be considered. The Division agreed finally to exempt on-premise food and drink sales under $\$ 30,000$ per year, where total sales of the establishment did not exceed $\$ 150,000$. This proposal was completed up to the point of the Director's signature, but fell victim to the "status quo" policy at the end of 1952 .

\section{General Services}

The I 948 Census of Business reports 623,000 predominantly service establishments which had an aggregate sales volume of 12.6 billion dollars in 1947. The average volume per establishment was, therefore, $\$ 20,000$. These figures do not include the vast number of stores which were predominantly sellers of merchandise, ranging from tire and battery dealers to department stores, that also do an important volume of service business. It is estimated that there are at least $2-1 / 2$ million firms selling services and that the sales of these services exceed 20 billion dollars annually.

In imposing price control on the service industries, OPS faced not only those problems that derive from smallness, i.e., lack of records, etc., but also the all-important facts that (I) labor is the principal element in the cost of a service, ranging from 60 to 95 per cent of total costs; and (2) in a vast number of establishments, services and commodities are sold together, sometimes "packaged" separately (auto repair), sometimes the service sold being incidental to the sale of a commodity (service warranty that is bought with a television set).

Considering the heterogeneous complex of trades (estimated at 500 to 600 ) which constitutes the services area, OPS adopted a freeze type of control (CPR 34$),{ }^{11}$ with an individual adjustment provision (Section 20(a)) which would relieve squeeze hardships suffered by service enterprises as their wage costs rose.

It was recognized that the data necessary to determine the amount of financial hardship under the adjustment provision could not be obtained from very small firms. Consequently, under the OPS operating instructions, sellers with a volume under $\$ 15,000$ (later raised to $\$ 25,000$ ) could be granted an increase in their ceiling prices up to "prevailing level." This short cut appeared liberal-but no more so in practice than what turned out to be a similar policy toward the giant enterprises in the petroleum field. In any event, the nature of the situation required some such treatment for speedy processing.

One conclusion necessarily deriving from the situation and the program adopted is that administration of the services' control must logically be delegated to the field organization. The field offices repeatedly asserted that there was inordinate delay in delegating the service program. Nevertheless, applications under "20(a)" con-

${ }^{10}$ I7 FED. REg. 2750 (1952).

11 I6 FED. REg. 4446 (I95I). 
stituted the largest bulk of adjustment actions handled by OPS field offices, almost one third of the total.

Area adjustment of service ceiling prices for particular trades seemed to many field executives a logical and effective administrative policy. The national office had reservations.

In administering the service control program, local price boards could have played an important role. Even without such boards, which were established on a pilot basis only in the last days of OPS, many area adjustments for services were ordered, but almost entirely for the laundry and dry cleaning groups. It would appear that area treatment may hold promise of swifter and broader scale administration of adjustment programs in services than the cumbersome case-by-case process of individual filings with their inevitable delays.

\section{Construction Services}

The building industry is characterized by small enterprises, from the sand, gravel or concrete producer to the contractor on the site. There are many hundreds of thousands, possibly millions, of contractors in the industry, because in many of the building trades the skilled workmen is potentially a contractor and frequently does jobs as a private entrepreneur. This fluidity in the business and the great mass of enterprises which were subject to control posed serious, and in some cases unique, diffculties for OPS.

There were relatively few complaints about OPS regulations from the producers of building materials, although special situations arose, particularly with regard to increases in transportation costs. Building material prices had risen sharply before the imposition of GCPR, so that building materials producers were frozen into a relatively satisfactory profit position. An indication of this fact was that there were few applications for adjustments of prices from this group, above the basic raw material level, during the period of price controls.

GCPR froze prices of construction services as it did every other commodity or service. Charges for new jobs had to be the same as for a similar job in the base period. The cry immediately went up that you cannot assign the same charges for two jobs, because "no two jobs are alike." The GCPR standard of a same or similar commodity or service could not apply, since weather, site, and material delivery conditions might all be different on two jobs, although the superficial appearance of the jobs might indicate the same or similar price. Moreover, labor is the principal cost constituent of a construction contract, and labor costs continued to rise after January 26, $195 \mathrm{I}$.

The general services regulation, CPR 34, was first thought to be appropriate to construction services because it contained a recognition of formula pricing. Its weakness was that the element of materials' cost enters rather more substantially into construction work than into other services; and contractors were accustomed to base their charges on the current cost of materials and not to make particular 
reference to base period materials' costs. They objected strenuously, therefore, to the application of CPR 34 to this field.

CPR 93 was issued November I4, $195 \mathrm{I}^{12}$ as a tailored regulation for construction and related services. It imposed a squeeze on the profit margins in order to offset, if possible, increases in prices charged since Korea. The regulation called for a filing of service charges for all but "lump sum" contractors. This virtually excepted the big enterprises from a reporting requirement which was imposed on the small contractors.

It is believed that compliance with the filing requirement ran less than 20 per cent. ${ }^{13}$ The Branch placed the fault not on the regulation but on an inadequate education and compliance effort by the field offices toward the very small construction service contractor. The familiar painter, carpenter or roofer who serves a small community and works at small jobs is frequently no more than a self-employed workman. It is difficult, if not impossible, to impose the burden of reporting or record-keeping required by price controls on such small operators.

CPR 93 did provide for the exemption of "one-man" shops from price controls. This was done over vigorous objections of some of the staff of the Building Materials Branch. This exemption was extended later to all contracting service suppliers who did less than $\$ 25,000$ in business a year.

The area of construction services is so broad and so complex that it is difficult to see how a single regulation can cover it adequately. Nor can the same basic technique be applied to a small home-service electrical contractor and the giant firm that contracts a bridge, power plant or apartment house development.

The OPS program in construction services, so far as small business is concerned, did not work. In either its design or administration or both, it does not appear to have provided a sound prototype for future application.

\section{VII}

\section{OPS ReLIef For S MaLL Bustness}

The principal disproportionate difficulties suffered by small business under OPS price controls were caused by the price or profits squeeze, technical or accounting requirements of regulations, delays in processing individual price actions, especially adjustments, and reporting and record keeping requirements. A price control operation is inevitably painful. The patient will always complain to some degree. OPS administered many forms of pain killer with varying degrees of success. The principal methods of relief are described briefly below.

\section{A. Individual Adjustments}

A program of adjustment of prices is required in a price control program to relieve individual squeeze situations with minimum impact on the price level. It is necessarily designed for all businesses regardless of size. However, since

23 I6 FED. REG. II592 (x95I).

${ }^{13}$ Memoranda, Adams to Robison, Reporting System of CPR 93, July 30, 1952; and Robison to Phelps, Reporting Requirements under CPR 93, Aug. I, 1952. 
most businesses are small, it may fairly be said that individual adjustments are one of the principal means of relieving small businesses of an undue burden of price control. Such a program can never be handled satisfactorily to all concerned because of the very nature of the problem. In a control operation, financial hardship inevitably is created and frequently must be remedied through an appraisal of the situation in the individual small business.

In time, individual adjustments for small businesses constituted one of the continuing and extensive problems of the agency and probably the greatest workload of the field organization.

OPS developed four basic standards for individual adjustment of ceiling prices: financial hardship, essential supply, cost pass-through, and removal of inequities. The first three appeared in general overriding regulations; the last in special provisions of many individual regulations and in sub-regulations.

r. Financial Hardship Adjustments. In general, OPS considered a company not in hardship if it was earning a profit.

The principal mechanism for granting relief from financial hardship was GOR $\mathrm{ro}^{14}$ which was somewhat more liberal than the earlier requirements which it superseded. The regulation provided originally that manufacturers with volume under $\$ 250,000$ would file in the field offices, but this level was later raised to $\$ 1,000,000$. It should be noted that the operating instructions for GOR ro quietly authorized the field personnel to adopt a non-technical approach to applications from manufacturers with less than $\$ 50,000$ sales volume. Experience had indicated that many applications were faulty and lacked data needed for a decision as to a grant or a denial. Ordinarily, the applicant was requested to supplement his incomplete application with this additional material, at the cost of delay in processing. In the case of very small applicants, the unpublished policy was to make every effort to reach a decision on the basis of whatever data were submitted and without recourse to accounting analysis, with certain precautions.

Various reasons can be ascribed to the small number of applications under GOR I0. ${ }^{15}$ In the first place manufacturers were generally in a good profit position and few needed this kind of relief. Second, manufacturers in a loss position not infrequently are relatively high cost producers; since competitive conditions would tend to prevent their putting higher ceiling prices into effect, there was little point in their applying for higher prices. Third, while a manufacturer might be fully familiar with the tailored regulations applying to the commodities he sold, he was often unaware of the GOR; this was particularly true of small manufacturers.

One of the most widely used adjustment provisions was Section 20(a) of CPR 34 , the services regulation. ${ }^{16}$ This was designed basically to restore to service sellers

\footnotetext{
14 I6 FED. REg. 4455 (I95r).

${ }^{15}$ Applications under GOR Io totaled 1,144 of which 563 were processed in the national office and $58 \mathrm{I}$ in field offices.

${ }^{16}$ Applications totaled 9,454, of which 1,953 were processed in the national office and 7,501 in field offices.
} 
their pre-Korea margins. Under the operating instructions, very small sellers (under $\$ 25,000$ annual sales) were treated with greater liberality.

The general policy of measuring hardship below the break-even level was departed from in many supplementary regulations and adjustment provisions. One of the more interesting, with a special small business aspect, was $S R 39$ to $\mathrm{GCPR}^{17}$ which provided for individual (or group) adjustments of ceiling prices of contract motor carriers (truckers). This regulation permitted the adjustment of rates to levels which would yield the historical operating margin of the company or the industry, whichever resulted in lower rates. But, if an applicant sought an adjustment on only a segment of his total operation, he could be brought only to breakeven on that segment. In making an application for adjustment, carriers with gross revenues under $\$ 15,000$ could use a much simpler form than the larger operators.

2. Essential Supply Adjustments. In order to assure an adequate supply of commodities and services essential to the defense program and the basic civilian economy, OPS issued GOR $29^{18}$ to provide a more liberal adjustment than mere break-even. In effect, it applied the Johnston Industry Earnings Standard to the individual company, and admitted hardship if the company was earning less than 85 per cent of its return on net worth pre-Korea. Under special circumstances, an even more liberal treatment was permitted.

3. Capehart Adjustments. OPS endeavored constantly to limit and confine the pass-through of increased costs. The 195I Capehart Amendment ${ }^{19}$ required OPS to recognize all cost increases from a base period up to July 26 , I95I in establishing ceiling prices. The formula for calculating Capehart prices introduced rather complicated accounting data beyond the resources of many small businesses. This situation caused the issuance of the only OPS regulation for small business per se, GOR $20 .{ }^{20}$ It allowed a concern with annual net sales under $\$ 250,000$ to use a simplified accounting technique to calculate a Capehart adjustment of its prices on the basis of the operating experience of the entire enterprise. The permitted procedure was intended to "give the small businessman treatment generally equivalent to that which would be obtained by using more precise accounting methods."21

The manufacturers' regulations, CPR $22^{22}$ and $30,{ }^{23}$ were in themselves devices for allowing manufacturers whose selling prices had lagged behind rising material and labor costs to readjust the relationship to a pre-Korean basis. The large body of "modified freeze" regulations provided this type of adjustment of ceiling prices.

4. Other Cost Pass-Through Adjustments. Increases in transportation costs, authorized by the ICC, state regulatory bodies, and the Post Office worked con-

${ }^{17}$ I6 FED. REG. 7150 (195I).

${ }^{18} 17$ FED. REg. 4762 (1952).

${ }^{10} 65$ StAT. 134 (I95I), 50 U. S. C. App. \$2102(d)(4) (Supp. 1952).

${ }^{20} 16$ FED. REG. I2014 (I95I).

31 Statement of Considerations, GOR 20.

${ }^{23}$ I6 FED. REG. 3562 (I95I).

${ }^{33}$ Id. at 4108 (I95I). 
siderable hardship on delivered price sellers as against f.o.b. sellers—and in reverse with respect to buyers. This discrimination needed to be cured and various supplementary regulations were issued in 1952 to ameliorate the situation for delivered price sellers. ${ }^{24}$ In general, manufacturers were required to treat inbound freight increases like any other cost increase.

Another type of cost pass-through was that allowed to metal processors to offset increases in base metal prices which occurred in the summer of 1952 . GOR $35^{25}$ was the principal vehicle for these industry adjustments. It obviated the processing of innumerable individual GOR 29 applications since many metal processors could have qualified under the essential supply standard.

5. Fairness and Equity Adjustments. Not only does a general freeze catch and hold distorted price and competitive situations, but tailored regulations, curing some of these, create other distortions. In most industries, businessmen-and the small ones are almost always in the majority-had access to adjustment provisions that recognized possibly unfair and inequitable requirements of the governing regulation. It will serve the purpose of this paper merely to mention the principal conditions under which an individual adjustment could be granted on the basis of fairness and equity:

Introductory offers in the base period

To permit conformance with federal and state requirements

To set uniform prices

Change of billing from f.o.b. to delivered basis

Conformance to parity requirements

To change from abnormal to normal base period

To maintain customary price-relationships in a product line

To reflect a change in competitive factors since base period

\section{B. Self Executing Adjustments}

One of the principal annoyances and costs of price control is the length of time it takes to answer an application for adjustment. Whether the decision is a grant, partial grant or denial, the businessman wants to know promptly. Delays keep business planning in suspense. Where an increase in the ceiling price is clearly justified, the profit margin is unduly squeezed while the application is being processed. There were more than a few cases in which OPS took 6 months to a year to issue a letter order on an adjustment application. ${ }^{26}$

Because OPS was always plagued with a lack of adequate personnel to process applications, a trend developed to make adjustment applications self executing, generally after a waiting period. The agency reserved the right to review the file, and modify or deny the adjustment later if it found good cause.

\footnotetext{
${ }^{24} \mathrm{SR} 28$ to CPR 22 and SR 106 to GCPR on June 19, 1952, 17 FEd. REg. 5610, 56r2; SR 9 to CPR 30 and SR 122 to GCPR on Oct. 2,1952 , id. at 8842,8845 .

25 17 FED. Reg. 8179 (I952).

${ }_{20}^{\circ}$ The record on applications under CPR $3 I$ (I6 FED. REG. 4184 (I95I)) (imports) was particularly unhappy.
} 
The Capeheart adjustments under the general manufacturers' regulations were outstanding examples of self-executing adjustments. They were SR I7 and 18 to CPR 22, ${ }^{27}$ and SR 4 and 5 to CPR $30^{28}$ SR I8 and 5 provided simplified techniques for manufacturers with sales volume under $\$ \mathrm{r}, 000,000$.

\section{Premium Pricing}

In many fields, the small business traditionally obtains a higher price than its big competitor for a particular commodity or service, and traditionally prices on a higher gross margin of profit. OPS was committed to customary trade practices. Since most of the basic commodity regulations attempted to restore pre-Korean margins, they tended to support this basic difference in pricing policy. However, a corollary of this policy was that if a small company had a narrower-than-average margin or a low competitive price pre-Korea, it was expected to remain in that position relative to its competition. CPR 7 (supra, note 6), for example, established the ceiling margin for any category of goods sold by a retail store on the basis of actual invoices and selling prices of the individual store.

In contrast with general merchandise retailers, grocery stores tend to compete to the penny within a class, and consequently have practically identical margins. On this assumption, OPS established specific ceiling margins for grocery stores and in doing so recognized that small stores traditionally took a bigger unit profit than large stores. CPRs $15^{29}$ and $16{ }^{30}$ issued March 28, I951, established different markups for four size groups in the grocery field. The dividing lines according to sales volume were: Group I- "independents" under \$76,000; Group 2-“independents" under \$375,000; Group 3-“non-independents" under \$375,000; and Group 4-over $\$ 375,000$. The following table gives typical differences in markups over cost permitted by CPRs I5 and I 6 to the several classes of stores.

Permitted Markups Over Cost

$\begin{array}{lcccc} & \begin{array}{c}\text { Group I } \\ \text { Per cent }\end{array} & \begin{array}{c}\text { Group 2 } \\ \text { Per cent }\end{array} & \begin{array}{c}\text { Group 3 } \\ \text { Per cent }\end{array} & \begin{array}{c}\text { Group 4 } \\ \text { Per cent }\end{array} \\ \text { Breakfast cereals } & 24 & 22 & \text { I8 } & \text { I6 } \\ \text { Coffees } & 17 & \text { I7 } & \text { I2 } & \text { II } \\ \text { Dog and Cat Foods } & 27 & 27 & 24 & 24 \\ \text { Canned soups } & 27 & 26 & 19 & \text { I9 } \\ \text { Butter } & \text { IO } & \text { 10 } & \text { I0 } & \text { 10 }\end{array}$

In an exceptional case, OPS did grant small operators a premium over the going ceiling price for an industry. SR $4 \mathrm{I}$ to $\mathrm{GCPR}^{31}$ allowed sellers of brown iron ore in the southeastern states to charge 2 cents more than their GCPR ceiling. It was done to encourage production of this ore for defense purposes, and because most of the mines involved were small, producing less than 60,000 tons per year. The benefit, however, did flow to the few larger mines as well.

\footnotetext{
${ }^{27}$ I6 FED. REG. II 484 , IIgIg (I95I).

${ }^{28} \mathrm{Id}$. at I I 496, 12869 (I95I).

${ }^{30} I d$. at 2750 (195I).
}

${ }^{29}$ Id. at 2735 (I95I).

${ }^{31}$ Id. at II 27 I (I95I). 


\section{Alternate Pricing Methods}

OPS recognized from the beginning that its regulations might be couched in terms too technical for the small businessman. Consequently, it made such regulations mandatory to all but the very small operators. The latter could, if they wished, remain under GCPR and forego whatever benefits the tailored regulations afforded.

CPR 7, for example, originally permitted retailers with a volume under $\$ 20,000$ in CPR 7 goods to retain their GCPR prices and not file the CPR 7 charts. ${ }^{32}$ Amendment 5 , issued May 28, $195 \mathrm{I}^{33}$ extended the option to retailers with annual volumes of $\$ 60,000$ and $\$ 100,000$, depending on the kinds of goods sold in the store.

Similarly, small manufacturers with annual volume under $\$ 250,000$ could retain their GCPR prices or elect to price under the manufacturers' regulations, CPRs 22 and 30 (supra notes 22 and 23 ). In the adjustment area, small manufacturers who could use the simplified techniques of GOR 20 (supra note 20) to figure their Capehart adjustment were permitted to file under GOR $2 \mathrm{I}^{34}$ if they wished. The latter required much more detailed accounting data, but the GOR 2I formula sometimes resulted in a higher adjusted price than the short-cut method. ${ }^{35}$

The GCPR itself contained an alternative method provision, Section 7 , which became virtually a standard form in all tailored regulations. It permitted any seller who found it impossible to price a commodity or service under the approved methods detailed in previous sections to apply to OPS for the establishment of a ceiling price. Such applications were filed with, and authorizations issued by, the district offices, except for manufacturers with sales volume over $\$ 250,000$ and groups of retail sellers located in several regions.

The comparable section in CPR 34, which was directed primarily to small firms, permitted service sellers who applied for a price authorization to put the price into effect 20 days after filing the application unless OPS intervened with a disapproval or a request for additional information.

There were many other situations in which OPS permitted sellers an option among several methods of pricing. Such options were generally available to any manufacturers of the particular commodity, large or small, but in most cases the alternatives were particularly appropriate to the smaller business which did not normally maintain the records of large operators. Examples of optional pricing methods are found in $\mathrm{CPR} 30$, SR I; ${ }^{38} \mathrm{CPR} 30$, SR $8 ;{ }^{37} \mathrm{CPR} 67$, SR $2 ;^{38}$ and many other regulations.

${ }^{32}$ The Final Report of the House Small Business Committee comments: "Actually, in many cases this turned out to be no choice at all. Under GCPR, the operator was faced with decreased profits, caused by an absorption of increased costs. On the other hand, the use of CPR 7 might permit a larger margin of profit .. . but profit benefits were nullified by extra administrative expense incurred in handling the extensive bookkeeping and paper work required by the new regulation. Either way it appeared to be a losing proposition."

${ }^{33}$ x6 FED. REG. 5008 (195I). 34 Id. at 12310 (195I).

${ }^{36}$ See also SR 18 to CPR 22, 16 FEd. Reg. $x$ rgrg (r95I), and SR 5 to CPR 30, I6 Fed. Reg. r2869 (r95x).

${ }^{36}$ I6 FED. REG. 4692 (195I). $\quad{ }^{37}$ I7 FED. REG. 8837 (1952).

${ }^{88}$ Id. at 5722 (I952). 


\section{E. Relaxation of Record Keeping and Reporting}

A price control program without record keeping or reporting is unenforceable and unthinkable. At what point records and reports become excessive is a matter of opinion, and in the lifetime of OPS opinions differed strongly. The agency was constantly be-labored with the charge that it required unnecessary records to be kept and impossible reports to be filed, all of which imposed a needless burden of expense on industry.

OPS had some defense in the fact that it had to justify and clear every record keeping and reporting requirement in its regulations with the Bureau of the Budget.

Responding to pressures from outside the agency, both the Director of Price Stabilization and the Director of the Office of Price Operations repeatedly urged the Commodity Divisions to eliminate unnecessary record keeping and reporting. A special assistant was assigned early in 1952 to the task of prodding the divisions in this direction. But every division had "a very good reason" for keeping its treasured provisions and the Enforcement Office could usually be depended on to uphold the stand-pat position.

For example, with compliance estimated at about 20 per cent, the Bureau of the Budget threatened to withhold continuing permission to use OPS forms Ior, r02, 103, and ${ }^{0} 4$ on which construction service contractors filed their ceiling charges under CPR 93 (supra note 14 ). It saw the whole project as futile. The Building Materials Branch felt that the filing was essential to control-although reports indicated that prices were not pressing ceilings. In other words, there was violation of a reporting requirement but not of price ceilings. Enforcement and the Branch agreed on a drive to obtain greater compliance and the Budget Bureau reluctantly agreed to extend the use of these forms. The discussions and negotiations took months and before the drive was started the national elections were held, continuation of the program came into serious question, and the drive was indefinitely deferred.

There was, in fact, very little repetitive reporting under OPS regulations. That little became largely optional after Section 4 II was added to the Defense Production Act in $1952^{39}$ However, even one-time filings were protested by industry; and record "making," such as was required under CPR 7 , and the various meat regulations drew criticism on the agency throughout its existence. Late in I952, under the stimulation of the general relaxation program, review of regulations did lead to progressive lifting of reporting and record keeping. Examples are Amendments 2 and 3 to CPR $33^{40}$ Amendment 2 to CPR $134^{41}$ Revision of SR 6 to CPR 22; $;^{42}$ Amendment 3 to SR 22 to CPR $34 ;^{43}$ and Amendment 55 to CPR $22 .{ }^{44}$ In the critical area of meats, modifications were effected in DR r, CPRs 23, 24, 74, 92, and ror.

${ }^{30} 66$ STAT. 296, 304 (1952).

11 Id. at 5518 (1952).

"s Id. at YIIIZ (1952).

${ }^{40}$ I7 FED. REG. I0506, I1226 (1952).

49 Id. at 7422 (1952).

"Id. at 8187 (1952). 


\section{F. Exemptions}

OPS started with a general policy of no exemption for small business-with one exception. The agency stated in its first action, GCPR, that its intention was "to include within its scope all sellers of all commodities and services except to the extent that legal or strong practical reasons require that particular sellers or types of commodities be exempt."45 Within these criteria, the agency exempted:40

Sales or deliveries of commodities made or produced by the seller at his home, solely for his own account, without the assistance of hired employees, if the total of such sales or deliveries does not exceed $\$ 200$ in any one calendar month.

The development of policy is reflected in subsequent expansion of the exemption, by raising the monthly ceiling first to $\$ 1,000$, ${ }^{4 \pi}$ and later to an annual volume of $\$ 25,000$ without limiting it to personal production in the home. ${ }^{48}$ It was deemed that "exemption of these small producers will have no appreciable effect on the cost of living, the defense effort or the level of current industrial costs." 40

Comparable to the exemption of the small home manufacturer was the exemption of construction services performed by one-man firms under CPR 93 issued in November 195 I. A rather liberal small firm exemption was that granted to printers with an annual volume under $\$ 50,000.0^{50}$

The agency exemption policy was stated in POM No. 5, first issued on August 5, I95I, revised and liberalized on August 2I, I952. Under this policy, an increasing number of industries were exempted as insignificant to the cost of living or administratively difficult if not impossible to control. Early examples are found in the exemption of precious stones and precious jewelry (Amendment 2 to GOR $5)^{51}$ and of the service of driving, booming, and rafting pulpwood in New England and New York (Amendment 2 to GOR 8). ${ }^{\mathbf{2}}$ This program was expanded and accelerated in the spring of $195^{2}$ as a part of the general relaxation program.

In general, it may be said that in the early days OPS did not generally favor exemption of small firms. Administrative difficulties of control, pressures from small businesses and from Congress, coupled with a softening price level, finally resulted in a very substantial exemption program. This wound up with a strong effort on the part of the staff to put through a firm, across-the-board small business exemption program. However, the small business exemption proposal for retailers and wholesalers reached third base (the Director's desk) but was stranded there by the "status quo" policy adopted in December 1952.

45 Statement of Considerations, GCPR; Jan. 26, r951.

"Section 14, which provided for exceptions and exemptions under the "legal" or "practical" criteria.

${ }^{47}$ Amendment 19, Oct. 9, 195I, x6 Fed. Reg. 10310 (1951).

${ }^{48}$ Amendment 33, Aug. 15, I952, I7 FED. REg. 7487 (1952). Producers of saw logs, pulpwood, and related forest products were not included.

${ }^{40}$ Statement of Considerations, Amendment 33 to GCPR. At this time, Amendment 54 to CPR 22 extended a similar exemption to small manufacturers under that regulation. I7 Fed. REg. 7486 (1952).

${ }^{50}$ CPR I21, Jan. 29, I952, I7 FED. REG. 888 (1952).

${ }^{51}$ I6 FED. REG. 5870 (I95I).

${ }^{82} \mathrm{Id}$. at 5989 . 
VIII

\section{A Sirall Business Regulation}

There was strong support in OPS for the belief that "in many cases, perhaps most, a double pricing system for large and small business can neither be devised nor justified." It is clear, nevertheless, that, except for a flat price regulation, any technique of price control which is designed to cover all contingencies and be effective with respect to large businesses will impose disproportionately large burdens of record keeping and reporting on small businesses.

If price control is to give "special consideration" to small business, and that is the determined policy of the Congress, regulations must not only be written in simple language, but also be very simple in their terms and requirements. Against this objective are the undisputed problems which must be met in devising a small business regulation. Among them are the following:

(a) If dollar volume of sales is to be taken as a measure of the size of a business, where is the proper cut-off to define small business? Should this apply across-theboard or is a different cut-off level to be selected for different types of business? For example, if merchandise sellers under $\$ 50,000$ are to be considered small business, that figure is certainly too high for grocery stores. Taking a \$15,000 figure because that applies more appropriately to the grocery store trade, it is certainly insignificant and will effect little advantage to the merchandise sellers.

(b) If the regulation is to be applied only to combination sellers, those who would normally be subject to several regulations, then small businesses which are not sufficiently diversified to come under the simplified regulation could make a pretense of adding one or two new products to their line, and so qualify for the simpler procedures.

(c) The small business regulation must necessarily involve provisions for special situations such as seasonal sellers, new sellers, and the pricing of new products.

(d) One must provide for adjustments. The agency criteria for adjustments may differ as between different trade or community groups and yet the single regulation must provide a simple adjustment mechanism applicable to all trade groups covered by the regulation.

(e) Certainly a general regulation must be cognizant of and provide for community and area pricing.

(f) It will, of course, result in unequal treatment to neighboring stores of slightly different volume. One store will be under the qualifying line and so enjoy liberal treatment under the small business regulation, while the store across the street may be just over the line and be required to adhere to more complicated requirements.

(g) That raises a new question as to what to do about sellers who cross the qualifying line from one year to another, either going over or falling below it.

However, a listing of the problems to be faced does not condemn the task as impossible. Two district offices, Oakland, California and San Antonio, Texas, did, in fact, draft and propose omnibus small business regulations. They got almost 
no support in Washington. When, after many months of complaints from the field, some interest was created in the national office, it was mid-1952, the price curve had turned down, and the easier solution of exempting small businesses appeared fully justified in the circumstances.

It should be noted that hope for a small business regulation was never completely given up. It was merely deferred, and the intention was to (I) exempt the smallest stores, (2) issue a combination regulation for the next higher bracket of establishments, and (3) leave the basic regulations to apply to the larger concerns. ${ }^{\text {b3 }}$

IX

\section{Exemption of S Mall Business}

At about the time the Committee on Relaxation of Controls agreed to explore the possibilities of a broad small business exemption, the Consumer Goods Division proposed to exempt all retail stores subject to CPR 7 that did less than $\$ 100,000$ per annum, an alternative to the apparently superhuman task of simplifying CPR 7 . The bulk of retail volume handled by the larger stores would still remain under control and the Division was confident that, even where prices tended to be firm, the pressure of competition from the larger stores would hold the exempted stores in line-a condition which cannot be depended upon in periods of very strong price pressures and inflationary buying.

Upon inquiry, most of the other Divisions indicated that they would cooperate in a general program to exempt the smaller businesses in their jurisdictions.

Attention was then focused on selection of appropriate cut-off levels for specific trade areas, depending on the distribution pattern for each particular trade. Data showed, for example, that if all so-called CPR 7 stores (including general merchandise, apparel, furniture, shoe, appliance, jewelry, etc.) with an annual volume of under $\$ 50,000$ were exempted, it would release 57 per cent of the stores from control, but this large number accounted for less than to per cent of total volume. ${ }^{54}$ However, within the group there were wide disparities. At a $\$ 50,000$ cut-off, in the gift and novelty category, 83.8 per cent of stores handling 63.8 per cent of the total volume of business by such stores would be released from control. In furniture stores, the comparable ratios were 39.1 per cent and 7.6 per cent. In services, a $\$ 50,000$ cut-off level would exempt $9 r .8$ per cent of all establishments doing 44.9 per cent of total volume, and a lower cut-off level was indicated.

It was realized, also, that there would have to be some basis for adjusting exemption levels by geographical areas, since obviously an exemption level for a metropolitan center could not be applied in a sparsely settled district. For example, a $\$ 50,000$ exemption for furniture stores would result in very few stores being exempted in New York City, while almost all stores might be exempted in South Dakota.

${ }^{53}$ Memorandum, Small Business Committec to Freehill, Nov. 17, 1952.

54 Based on 1948 Census of Business. . 
This prospect suggested two alternatives: (I) in each trade different exemption levels would be set for several types of trading areas, ranging from high cut-off points for large metropolitan centers to low ones for rural areas, or (2) national exemption levels could be modified for a trading area by, or at the suggestion of, the regional offices in accordance with criteria established by the national office. The first was out of the question from an administrative viewpoint.

However, if the regional offices were given any authority in a flexible exemption program, they would face local pressures to raise exemption levels. These pressures would be very hard to resist, since they would probably be brought personally upon the staffs of the regional and district offices and would be supported by strong local groups.

It was decided, therefore, to set the exemption levels low rather than high as an additional safety factor.

The use of 1948 census data provided a further factor of conservatism. Prices had increased substantially since 1947 , and the average dollar volume per store had certainly increased. Consequently, at any cut-off point the effective exemption would be less than indicated by the census data.

While it was clear that (I) some authority with respect to modifying exemption levels had to be accorded to the regional directors, or some other body having an intimate and direct knowledge of trade characteristics within an area, and (2) pressures on the local authority would tend toward expanding the extent of exemption, it was also possible that in a few cases a regional director, opposed in principle to exemption, would want to lower exemption limits, perhaps to levels that would effectively nullify the policy. It was decided, therefore, that, while the regional director (or other local authority) should have power to modify exemption levels, both up and down, this delegation might have to be limited.

As finally developed, the cut-off levels were designed to exempt roughly 50 per cent of the number of establishments (in each business category) handling no more than 20 per cent of the volume, ${ }^{55}$ with $\$ 10,000$ annual volume fixed as the lowest feasible exemption level.

The proposed regulation contained a significant omission-small restaurantsfor which a special exemption regulation was to be issued simultaneously with the general decontrol action.

It was also decided to exempt wholesalers at the general level of $\$$ roo,000. Manufacturers were not included because at this time it was assumed that they were being treated equitably in a series of amendments to the individual manufacturers' regulations.

At long last, the proposal had cleared all intra-agency hurdles, up to the Director's approval. But following the national elections, it was decided that "no major action be taken as to decontrol. ..." The "status quo" policy of ESA effectively laid to rest the proposal to exempt small business.

${ }^{60}$ Memorandum, Phelps to All Regional Directors, Oct. 23, 1952, with draft regulation attached. 


\section{CONCLUSIONS AND RECOMMENDATIONS}

The conclusions and recommendations developed in the course of this study are necessarily conditioned by the experience of OPS. That experience, in turn, was the product of the enabling legislation, the economic situation, and the political climate. Since a future need for price controls will certainly not develop in an identical complex of economic and political forces, the conclusions and recommendations below must be modified to the circumstances to which they may be applied.

\section{A. Policy Assumptions Toward Small Business}

I. The record keeping and merchandising practices of smaller businesses differ markedly from those of big business. Reliance cannot be placed to the same extent on (a) record resources concerning base periods, (b) ability to compile current records, or (c) reports. Consequently, in some trade and commodity areas different techniques of price control should be applied to large and small businesses.

2. Since small business, on the whole, commands less financial strength than big businesses, less assurance of low cost supplies in periods of intense demand, less diversity in operations and vertical integration, it is less able to withstand financial squeezes imposed by price regulations. Serious damage to the survival ability of a small business may be caused by a more than brief contraction of profit or interference with normal merchandising practices.

3. Small business traditionally operates in many lines on wider gross margins of profit than big business. Price control techniques should reflect this difference where it normally exists.

4. Prices of most small sellers are normally influenced if not determined by the competition of large sellers. Unless inflationary pressures are both strong and allpervasive, this will still be true during a period of price controls, at least in some segments of the economy. To the extent to which this condition prevails, control techniques may be modified to advantage, either applying less rigid controls to small sellers or exempting them. The cost of enforcing complicated regulations on a multitude of small sellers may outweigh the value of the effort. Any program or method adopted for control of small business should be evaluated in terms of (a) contribution to more effective stabilization in the particular field, and (b) diversion of manpower from more fruitful areas.

B. Organizational Arrangements for Small Business Representation

I. When everyone is impressed with a responsibility to look out for small business, practically no one does so. Consequently, the desired orientation can be assured only if small business is separately recognized in the control agency's organization.

2. Efficient management cannot tolerate authority over the total structure by a subsidiary office. Hence, in a price control organization, small business must necessarily occupy a staff position with restricted operating responsibilities.

3. Since ease of communication to every level of the orgainzation must be assured, 
the small business function should be focused at the top policy level. The OPS arrangement of an Assistant to the Director for Small Business can function effectively.

4. The Assistant for Small Business should be responsible for the development of special regulations, adjustment provisions, exemptions, and other program expressions of the small business policy. To carry out the reponsibilities, he must have sufficient staff (a) in his own office and (b) by detail whenever necessary from the staffs of the operating divisions.

5. Since a primary function of the field organization is to serve small business, the Assiştant for Small Business should have a stronger and more persuasive position in the field-control structure than was the case in OPS. However, the better the program is adapted to the peculiar needs of small business, the less important becomes the Small Business Assistant's function in field management. Basically, this position calls for functional direction rather than administrative control.

\section{Program for Small Business}

I. In virtually any economic climate some exemption of small business can be justified on the basis of (a) relief of work load on the agency, (b) relief to small business from the restrictions on activity and from administrative burdens, and (c) little or no unstabilizing effects on price. Exemption limits must be determined by (a) the economic situation and (b) the personnel available to the agency.

2. For that bracket of small business above the ranks of the smallest exempted group, regulations might be couched in terms of trades rather than commodities. This would tend to cure the situations found under OPS of multiplicity of regulations affecting small operators.

3. A program of optional special small business regulations and sub-regulations should be extended more widely than it was by OPS.

4. Area orders, dollars-and-cents regulations, and posted price programs tend toward easier compliance by small business and should be undertaken whenever possible.

5. Adjustments might be self executing at the small business level-with maintenance of records or reports as insurance of compliance.

6. Administration of the program, educational efforts, and assistance to small business in complying with requirements of regulations should be delegated as speedily as possible to the largest network of field offices that the budget will allow. 